\title{
Before and after wasting disease in common eelgrass Zostera marina along the French Atlantic coasts: a general overview and first accurate mapping
}

\author{
Laurent Godet $^{1, *}$, Jérôme Fournier ${ }^{1}$, Marieke M. van Katwijk ${ }^{2}$, Frédéric Olivier ${ }^{1}$, \\ Patrick Le $\mathrm{Mao}^{3}$, Christian Retière ${ }^{1}$
}

\begin{abstract}
${ }^{1}$ Muséum National d'Histoire Naturelle, Département Milieux et Peuplements Aquatiques, Station marine de Dinard USM0404 - UMR 5178 BOME 17, Avenue George V, 35800 Dinard, France

${ }^{2}$ Radboud Universiteit Nijmegen, Department of Environmental Science, Postbus 9010, 6500GL Nijmegen, The Netherlands

${ }^{3}$ Institut Français de Recherche pour l'Exploitation de la Mer (IFREMER), Laboratoire Environnement et Ressources Finistère-Bretagne Nord, Station de St-Malo, 2 bis, rue Grout Saint Georges, BP 46, 35402 Saint-Malo Cedex, France
\end{abstract}

\begin{abstract}
We examined the original manuscripts of a French national survey conducted in 1933 on the state of common eelgrass Zostera marina beds along the French Atlantic coasts during the period when wasting disease struck the entire North Atlantic population in the 1930s. Based on GIS related techniques and old sets of aerial photographs, we present the first accurate mapping of the $Z$. marina beds before wasting disease occurred and assess their spatial recolonization since the 1950s in the Chausey Archipelago (France), which contains large Z. marina beds. The national survey confirmed that the $Z$. marina beds almost totally disappeared from the French coasts during the 1930s. However, the disease symptoms seem to have begun locally a few years before. On the study site, we found that the $Z$. marina beds were more than twice as extended than as they are today, and covered both subtidal and intertidal areas. By the 1950s, 20 yr after the onset of the disease, the beds had hardly recolonized, and contrary to the recolonization patterns reported elsewhere in Europe, they were mainly restricted to subtidal areas. The subtidal and intertidal $Z$. marina beds on the site are now rapidly expanding.
\end{abstract}

KEY WORDS: Zostera marina $\cdot$ Common eelgrass $\cdot$ Wasting disease $\cdot$ Long-term change $\cdot$ Accurate mapping $\cdot$ France

Resale or republication not permitted without written consent of the publisher

\section{INTRODUCTION}

Wasting disease has been responsible for most of the decline of common eelgrass Zostera marina populations in the North Atlantic, affecting all populations in the 1930s (Rasmussen 1977, den Hartog 1987). In addition to the numerous debates about the cause of this disease (for reviews see Rasmussen 1977, den Hartog 1996), other questions concerning this phenomenon are still outstanding.

It is generally accepted that the disease was very significant, striking $90 \%$ the North Atlantic population of the species (Muehlstein 1989), and occurred from 1931 in North America and 1932 in Europe (den Hartog 1987). However, only a few documented cases allow us to assess how significant this disease was over large scales (e.g. the level of degradation of the beds over an entire country). Interestingly, some historical data also revealed that wasting disease-like damage patterns were recorded before the 1930s (den Hartog 1989).

Moreover, the state of the beds before the disease occurred is poorly known (den Hartog 1987). Because of the scarcity of older documents, the scientific community is still uncertain about the former areal extent of the beds, and their former bathymetric positions. The map of Oudemans et al. (1870) of the Dutch Wad- 
den Sea is probably the oldest map of Zostera marina beds known to exist before the disease struck, and is followed by maps from 1901 in Denmark (Boström et al. 2003). In France, the only pre-disease map of Zostera beds was published by Joubin (1909) of the Roscoff area, and sketches were made by De Beauchamp \& Lami (1921) of Bréhat and by De Beauchamp (1923) in the Ile de Ré. In Germany, Nienburg (1927) performed a rough seagrass distribution map (Z. marina and Z. noltii) of the Königsbay (Sylt) in 1924 (Reise et al. 1989).

A few authors used these old data to study in more detail the ecology (de Jonge \& Ruiter 1996) or the evolution of the beds before and after the disease occurred. Den Hartog \& Polderman (1975) and de Jonge \& Ruiter (1996) used the data of Oudemans et al. (1870) on the Wadden Sea, Blois et al. (1961) and Jacobs (1979) used the data of Joubin (1909) in France, Reise et al. (1989) used the data of Nienburg (1927), and van der Heide et al. (2007) used the 1931 map of Reigersman et al. (1939). However, these older documents have to be used with great caution for several reasons. First, there is a risk of confusion with other Zostera species; for example, Joubin (1909) mapped all the Zostera beds, mixing the 2 species ( $Z$. marina and $Z$. noltii) so that the distinction between the 2 species a posteriori can be hazardous. Second, these older documents did not allow accurate mapping, and they can be difficult to compare with mapping based on aerial photographs. Also, the estimations of superficies can be difficult, especially when it comes to distinguishing different bathymetric levels covered by the beds. Thus, additional calculations were required to determine the extent of error (see de Jonge \& Ruiter 1996). Finally, studying the spatial patterns of recolonization of the beds before and after the disease on a particular site is all the more interesting because the site has not been strongly affected by anthropogenic activities. The western Wadden Sea radically changed after the closure of the Zuyderzee. It was subjected to significant, but not well documented, increases in turbidity, eutrophication and fishery activities (den Hartog \& Polderman 1975, de Jonge \& Ruiter 1996, van Katwijk et al. 2000, de Jonge \& de Jong 2002, van der Heide et al. 2007).

Up to now, the earliest maps of Zostera marina beds performed through photo-interpretation in Europe have been those made in 1932 by Glémarec et al. (1996) of the Glénan Archipelago in France during the time when the wasting disease occurred. However, a large part of their study area was hidden by cloud cover and, thus, many photos were not optimally usable. Consequently, no accurate spatial reference state of the Atlantic seagrass beds has been produced since before the 1930s. To study the temporal changes in the eelgrass stands we used a French national survey of 1933 and a series of aerial photographs available from the years 1924, 1953, 1982, 1992 and 2002.

In this paper we aim to (1) assess, on a large scale, the dates of the first occurrences of wasting disease along the French coasts and the level of degradation of the beds, and (2) accurately assess for the first time the spatial evolution and the bathymetric position of the Zostera marina beds before and after the disease, and their current state in a site hosting large beds of the species where anthropogenic pressures during the 20th century have been minor.

\section{MATERIALS AND METHODS}

On 13 March 1933, a French military ministerial dispatch was sent to each district of the Affaires Maritimes about the disease affecting Zostera marina. We explored all the original manuscripts currently stored in the French Museum of Natural History. Eight questions were addressed, but here we focused on only two: (1) 'Are the seagrass beds of your region in a worse state than in the past? Are they totally or partially destroyed?' and (2) 'When did the disappearance or the decline of the eelgrass of your region begin?' Because we noticed some confusion between the 2 species, Z. marina and Posidonia oceanica, found in the Mediterranean districts, we only dealt with data from the 82 districts of the Atlantic and the English Channel coasts.

Five aerial photographic mosaics were assembled with 5 sets of aerial photographs taken of the Chausey Archipelago in Normandy, France (Fig. 1) in the following years: 1924, 1953, 1982, 1992 and 2002. All the Zostera marina beds were mapped on a 1:1000 scale with Arcview 3.1 Software at each date. The extents of the beds at different bathymetric levels were calculated with GIS by intersecting the different layers corresponding to a bathymetric map (extracted from Tocquet et al. 1957) and the mapped $Z$. marina beds.

\section{RESULTS}

The national surveys revealed that almost all the Zostera marina beds of the French Atlantic coast and of the French-English Channel coasts partially or totally disappeared (Fig. 2). The disease occurred mainly in 1931 ( $\mathrm{n}=23$ districts) and $1932(\mathrm{n}=14)$, but also as late as $1933(\mathrm{n}=2)$. More surprisingly, occurrences of the disease were also recorded as early as $1930(\mathrm{n}=6)$ and even before that $(\mathrm{n}=12)$ (Fig. 2).

In 1924, the Zostera marina beds of the Chausey Archipelago covered 763 ha (Fig. 3). Though they 
occurred mainly on shallow subtidal areas (51\%), they ranged from deeper subtidal areas (13\%) to intertidal sandflats (36\%). In 1953, 20 yr after the first occurrence of wasting disease, the beds barely covered $8 \%$ of their 1924 area (60 ha), and were essentially restricted to subtidal areas $(84 \%)$. The recolonization continued

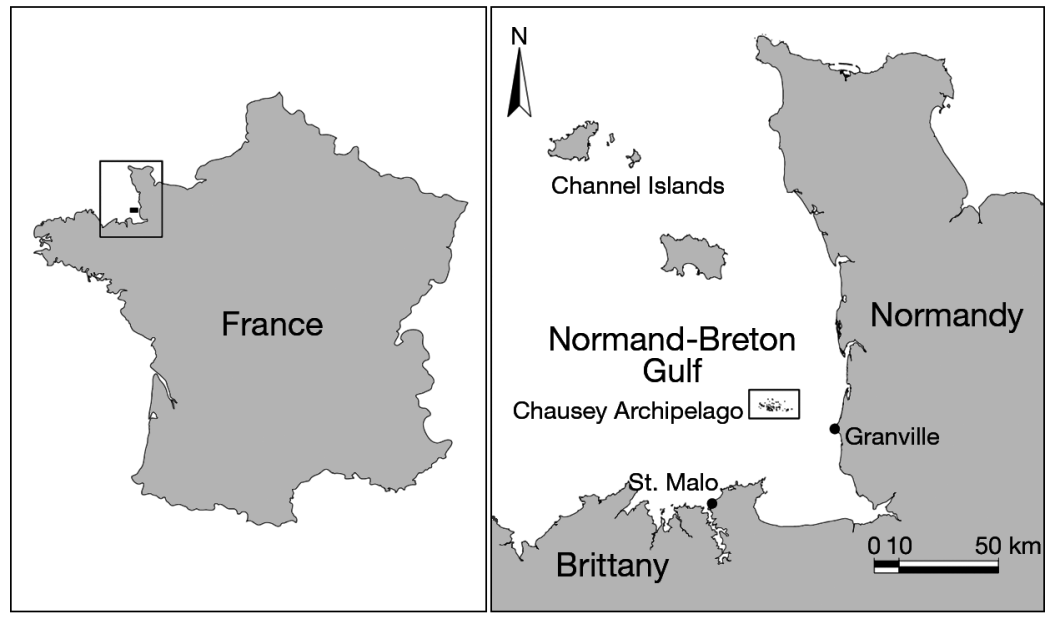

Fig. 1. Study site on the north coast of France. Expanded inset shows location of Chausey Archipelago in the Norman-Breton Gulf from 1953 to 2002, mainly in shallow subtidal areas, but the beds also extended to intertidal and deeper subtidal bathymetric levels. The development of the $Z$. marina beds was particularly important between 1992 and 2002 when the extent of the beds increased by $92 \%$. In 2002, though the bathymetric range of the beds was almost the same, they were still only half as extensive as they were in 1924 (Fig. 3).

\section{DISCUSSION}

\section{A significant outbreak emerges before 1932}

The 1933 French national survey showed that almost all the Zostera marina beds along the French coast (except along the Mediterranean Sea) were totally destroyed. This is important to know when looking at present day sites where the largest $Z$. marina beds exist, such as the Bassin d'Arcachon and the Golfe du Morbihan (Fig. 2).

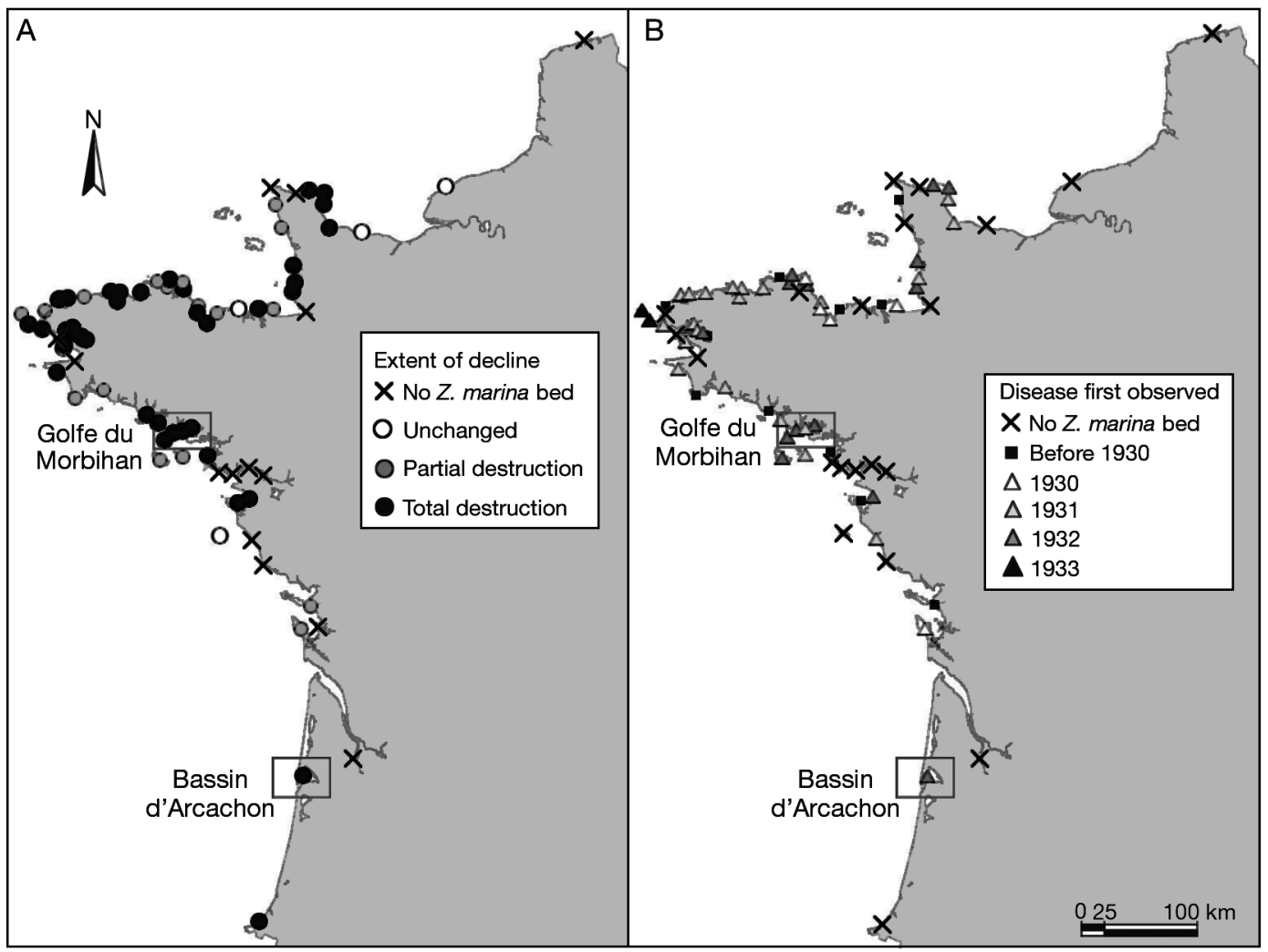

Fig. 2. Zostera marina. (A) Level of destruction of the eelgrass beds and (B) dates of the observation of the disease according to the survey of 1933. Boxed areas indicate location of largest present-day eelgrass beds 


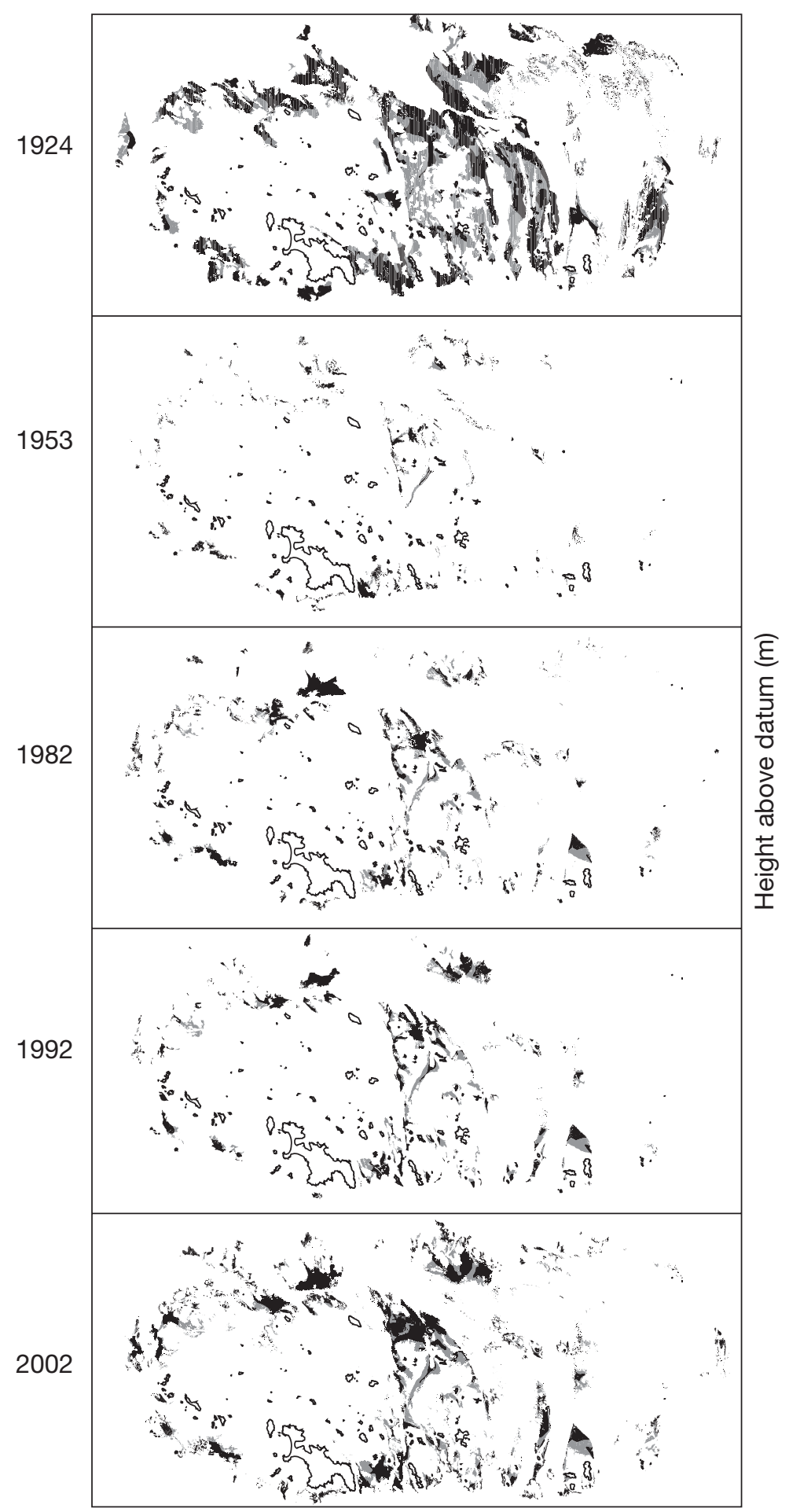

\section{Surface area (ha)}

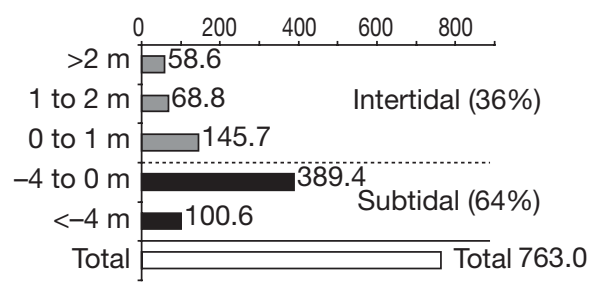

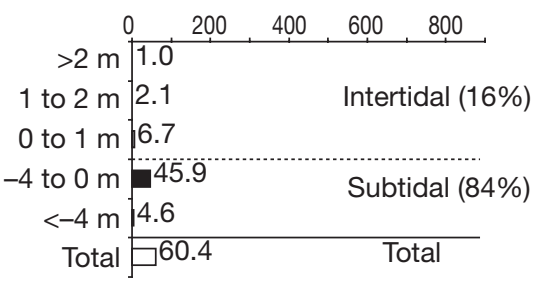

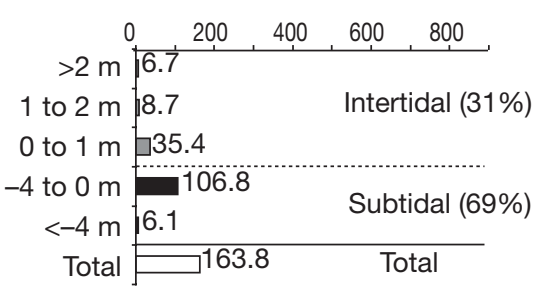

\begin{tabular}{|c|c|c|c|c|}
\hline \multirow{2}{*}{\multicolumn{5}{|c|}{$> 2 \mathrm { m } \longdiv { 5 . 8 }$}} \\
\hline & & & & \\
\hline 1 to $2 \mathrm{~m}$ & 10.8 & & Inter & dal (34\%) \\
\hline 0 to $1 \mathrm{~m}$ & 44.0 & & & \\
\hline $\begin{array}{r}-4 \text { to } 0 \mathrm{~m} \\
<-4 \mathrm{~m}\end{array}$ & 3.4 & & Sub & dal (66\%) \\
\hline Total & 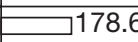 & & & tal \\
\hline
\end{tabular}

\begin{tabular}{|c|c|c|}
\hline \multicolumn{3}{|c|}{$0 \quad 200$} \\
\hline$>2 \mathrm{~m}$ & 12.8 & \\
\hline 1 to $2 \mathrm{~m}$ & 27.9 & Intertidal (32\% \\
\hline 0 to $1 \mathrm{~m}$ & $\mapsto 68.9$ & \\
\hline $\begin{array}{r}-4 \text { to } 0 \mathrm{~m} \\
<-4 \mathrm{~m}\end{array}$ & $24.8^{208.8}$ & Subtidal $68 \%$ \\
\hline Total & $\square^{32}$ & Total \\
\hline
\end{tabular}

$\square$ Isles and islets
$\square$ Intertidal $Z$. marina beds
Subtidal Z. marina beds

Fig. 3. Zostera marina. Spatial evolution of the eelgrass beds of the Chausey Archipelago since 1924. Datum (0 m, dotted line) in histograms: extreme low water (spring tide) 
The results of the 1933 survey confirm the ubiquity of the seagrass decline related to wasting disease observed elsewhere in North America and in Europe, where large beds totally disappeared. For example, in May 1932, all the Z . marina beds in the Dutch Wadden Sea were struck suddenly, and in a few days almost all beds had been infected and had died (den Hartog 1996).

Wasting disease is known to have occurred in 1931 in North America and in 1932 in Europe (den Hartog 1987), or around that same time period (Rasmussen 1977). This is partially confirmed by the 1933 survey. Nevertheless, the survey also reveals frequent reports of the disease occurring before 1930, as suggested by a few others. In Great Britain, Butcher (1934) recorded that Zostera marina beds had not been doing well since 1920. Early records of wasting disease-like damage before 1930 were also reported by den Hartog (1989) for the British Isles and The Netherlands when he studied herbarium materials of the British Museum and the Rijksherbarium of The Netherlands. As suggested by den Hartog (1989, p. 223), this may reveal that wasting disease is 'an inconspicuous, but widespread endemic phenomenon, normally occurring in eelgrass beds.'

\section{A slow recolonization from subtidal areas}

The 760 ha of luxurious Zostera marina beds of the Chausey Archipelago in 1924 had hardly begun to recolonize by 1954, and only reached $8 \%$ of their original surface area, essentially restricted to subtidal areas. We assume that they had almost totally disappeared between these 2 dates, probably between 1931 and 1932, as recorded in the national survey for this particular region (Fig. 2). Moreover, Lami (1933) reported that $Z$. marina beds were almost absent from the site in 1933, and even the large beds of more than 100 ha had not yet recovered by 1937 (Lami 1937). The time lag before recolonization began was long. Similar situations were also assessed in France in the 1950s. In the Glénan Archipelago, the Z. marina beds were scarce in 1952 and only began to improve in the 1970s (Glémarec et al. 1996). In 1957, the $Z$. marina beds around Roscoff were also scarce, and the recolonization really begun in the 1960s (Jacobs 1979). Elsewhere in Europe, the recovery was also very slow and $Z$. marina beds were still absent in a number of areas by 1951 to 1953 (Rasmussen 1973). In the Danish coastal waters, Frederiksen et al. (2004) observed a time lag of at least $10 \mathrm{yr}$ before recolonization began. In the Wadden Sea, subtidal beds never recovered, because turbidity related to suspended sediment was too high, probably because turbidity was no longer reduced by seagrass itself (positive feedback, van der Heide et al. 2007). Intertidal Z. marina beds in the Wadden Sea fluctuated considerably between 1932 and 1965, further declined during the 1970s (den Hartog \& Polderman 1975), and stabilised at 'near absent' levels in The Netherlands and at low levels in Germany since the 1990s (Reise et al. 2005, see www.zeegras.nl).

However, there is an important difference between the recolonization patterns of the Zostera marina beds of the Chausey Archipelago and those of other sites in Europe. In the Chausey Archipelago, recolonization was restricted to subtidal areas in 1953. In contrast, Jacobs (1979) concluded that the intertidal populations of $Z$. marina in the Roscoff vicinity were hardly affected by the disease. In The Netherlands, the Z. marina beds had been largely confined to subtidal areas before the disease occurred (van der Heide et al. 2007), but they only remained in intertidal and brackish areas after the disease was established (den Hartog \& Polderman 1975). In Devon, England, Wilson (1949) reported that the wide-leaved sublittoral $Z$. marina was replaced by a more narrow-leaved intertidal form, and this has not changed since (den Hartog 1987). These reports from other locations in Europe suggest a recolonization pattern from intertidal or brackish areas, which has been partly explained by an 'annual strategy' of these beds (den Hartog 1987). The intertidal recolonization patterns versus the subtidal ones we observed in the Chausey Archipelago can be explained in 3 ways.

(1) Until now, data about the recolonization patterns of the Zostera marina after the disease have been anec-dotal. Thus, it is still difficult to draw general conclusions over a large scale about any recolonization pattern either from subtidal or from intertidal areas. The few data only allow for site-by-site observations, and each observation has to be considered as a particular case.

(2) In the Chausey Archipelago, the optimal habitat conditions of Zostera marina correspond to shallow subtidal waters, where the species has been the most abundant over the 20th century, whereas in the Dutch or English coasts they correspond to intertidal areas and brackish waters. Consequently, the $Z$. marina beds only recolonize from their optimal living conditions areas after the disease has gone. However, this hypothesis differs from the results of Jacobs (1979) and Blois et al. (1961) who observed that recolonization patterns develop from intertidal areas, which are less affected by the disease, in the Roscoff region (160 km from Chausey), where the optimal living conditions of the species may be similar to those of the Chausey region. 
(3) The optimal habitat living conditions are subtidal, but recolonization may be more difficult in subtidal areas. This may be caused by 2 mechanisms or a combination of both: (a) the 'K-strategy' of the subtidal beds in comparison with the 'r-strategy' of the intertidal beds that colonize easily (e.g. Jacobs 1982), and (b) because light may be limited in subtidal beds after the disappearance of the plants as the plants may contribute to the local reduction of water turbidity, and low light levels occur particularly in turbid, eutrophic or otherwise affected areas like the UK or Dutch coasts (de Jonge et al. 2002).

\section{Present changes in Zostera marina beds: Does global warming matter?}

Large scale losses of Zostera marina beds have been recorded around the world in recent decades, and can largely be attributed to anthropogenic causes (Short \& Wyllie-Echeverria 1996, Orth et al. 2006a,b), although none, as yet, have been as catastrophic as that caused by the wasting disease of the 1930s (Short et al. 1986, 1988, 1993, den Hartog 1994). However, declines were also reported on sites where anthropogenic effects are considered to be minor, such as in the Glénan Archipelago beginning in the 1980s (Glémarec et al. 1996). Glémarec et al. (1996) blame the 2 declines of the 1930 s and those from the 1980s on global warming, following one of the hypotheses of Rasmussen (1973, 1977) who evoked a warming climate as a potential reason for the breakdown of $Z$. marina in Europe in the 1930s. Conversely, the $Z$. marina beds of the Chausey region have been developing in the last 2 decades, and particularly quickly since 1992. This is strongly contradictory to the global warming hypothesis. The long-term change of the $Z$. marina beds analysed in this paper suggests that the $Z$. marina beds are currently recovering in the colonized areas lost since the occurrence of wasting disease. This recolonization has been accelerating over the last decade, which is probably only due to a 'self accelerating process' (Hemminga \& Duarte 2000), related to positive feedbacks (see Duarte 1995, Munkes 2005, Bernard et al. 2007, van der Heide et al. 2007). Thus, we can suppose that at other sites in Europe and North America, the rapid development of human activities along the coasts is more likely to be the cause of the regression of the $Z$. marina beds than is global warming. Locally, human activities may also have positive effects on $Z$. marina beds development, as recently reported in the Ems estuary, The Netherlands, where the geomorphology dramatically changed due to the disposal of harbour sludge (de Jonge \& Brauer 2006).
Acknowledgements. We especially thank P. H. Norwood for improving the English of this manuscript and P. Danel and M. Bellouis for providing the old aerial photographs (IFREMERSHOM). We are also grateful to V. N. de Jonge and an anonymous referee for their constructive comments about the first version of this manuscript.

\section{LITERATURE CITED}

Bernard G, Boudouresque CF, Picon P (2007) Long term changes in Zostera meadows in the Berre lagoon (Provence, Mediterranean Sea). Estuar Coast Shelf Sci 73: $617-629$

Blois JC, Francaz JM, Gaudichon M, Gaudichon S, Le Bris L (1961) Observations sur les herbiers à Zostères de la région de Roscoff. Cah Biol Mar 2:223-262

Boström C, Baden SP, Krause Jensen D (2003) The seagrasses of Scandinavia and the Baltic Sea. In: Green EP, Short FT (eds) World atlas of seagrasses: present status and future conservation. University of California Press, Berkeley, CA, p 32

Butcher RW (1934) Zostera. Report on the present condition of eelgrass on the coasts of England based on a survey during August to October, 1933. J Cons Perm Int Explor Mer 9:49-65

De Beauchamp P (1923) Etudes de bionomie intercôtidale. Les îles de Ré et d'Yeu. Arch Zool Exp Gen 61:455-520

De Beauchamp P, Lami R (1921) La bionomie intercôtidale de l'Ile de Bréhat. Bull Biol Fr Belg 15:184-238

de Jonge VN, Brauer VS (2006) The Ems estuary. Changes in functioning and structure of a system under pressure. Department of Marine Biology, University of Groningen, Haren

de Jonge VN, de Jong DJ (2002) 'Global change' impact of inter-annual variation in water discharge as a driving factor to dredging and spoil disposal in the river Rhine system and of turbidity in the Wadden Sea. Estuar Coast Shelf Sci 55:969-991

de Jonge VN, Ruiter JF (1996) How subtidal were the 'subtidal beds' of Zostera marina L. before the occurrence of the wasting disease in the early 1930's? Neth J Aquat Ecol 30:99-106

de Jonge VN, Elliott M, Orive E (2002) Causes, historical development, effects and future challenges of a common environmental problem: eutrophication. Hydrobiologia 475-476:1-19

$>$ den Hartog C (1987) 'Wasting disease' and other dynamic phenomena on Zostera beds. Aquat Bot 27:3-14

den Hartog C (1989) Early records of wasting-disease-like damage patterns in eelgrass Zostera marina. Dis Aquat Org 7:223-226

den Hartog C (1994) Suffocation of a littoral Zostera bed by Enteromorpha radiata. Aquat Bot 47:21-28

den Hartog C (1996) Sudden declines of seagrass beds: 'wasting disease' and other disasters. In: Kuo J, Phillips RC, Walker DI, Kirkman H (eds) Seagrass biology: proceedings of an international workshop. Faculty of Sciences, University of Western Australia, Nedlands, p 307-314

> den Hartog C, Polderman PJG (1975) Changes in the seagrass populations of the Dutch Waddenzee. Aquat Bot 1: 141-147

Duarte CM (1995) Submerged aquatic vegetation in relation to different nutrient regimes. Ophelia 41:87-112

Frederiksen M, Krause-Jensen D, Holmer M, Laursen JS (2004) Long-term changes in area distribution of eelgrass 
(Zostera marina) in Danish coastal waters. Aquat Bot 78: $167-181$

Glémarec M, Le Faou Y, Cuq F (1996) Long-term changes of seagrass beds in the Glenan Archipelago (South Brittany). Oceanol Acta 20:217-227

Hemminga MA, Duarte CM (2000) Seagrass ecology. Cambridge University Press, Cambridge

Jacobs RPWM (1979) Distribution and aspects of the production and biomass of eelgrass, Zostera marina L., at Roscoff, France. Aquat Bot 7:151-172

Jacobs RPWM (1982) Reproductive strategies of two species (Zostera marina and Z. noltii) along the western European coast. In: Symoens JJ, Hooper SS, Compère P (eds) Studies in aquatic vascular plants. Royal Botanical Society of Belgium, Brussels, p 57-62

Joubin L (1909) Recherches sur la répartition océanographique des végétaux marins dans la région de Roscoff. Ann Inst Océanogr Paris 1:1-17

Lami R (1933) Etat de la flore marine dans la région malouine en 1933. Bull Lab Marit St Servan 11:11-13

Lami R (1937) Sur l'état de quelques herbiers de la région malouine en 1937. Bull Lab Marit Dinard 19:1-3

Muehlstein LK (1989) Perspectives on the wasting disease of eelgrass Zostera marina. Dis Aquat Org 7:211-221

Munkes B (2005) Eutrophication, phase shift, the delay and the potential return in the Greifswalder Bodden, Baltic Sea. Aquat Sci 67:372-381

Nienburg W (1927) Zur Okologie der Flora des Wattenmeeres. I. Teil. Der Königshafen bei List auf Sylt. Helgol Wiss Meeresunters 20:146-196

Orth RJ, Luckenbach ML, Marion SR, Moore KA, Wilcox DJ (2006a) Seagrass recovery in the Delmarva coastal bays, USA. Aquat Bot 84:26-36

Orth RJ, Carruthers TJB, Dennison WC, Duarte CM and others (2006b) A global crisis for seagrass ecosystems. BioScience 56:987-996

Oudemans CAJA, Conard JFW, Maats P Jr, Bouricius LJ (1870) Verslag der Staatscommissie in zake de wiermaayery. In: Verslag aan den Koning over de Openbare Werken in het jaar 1869, p 199-231

Rasmussen E (1973) Systematics and ecology of the Isefjord marine fauna (Denmark). Ophelia 11:1-507

Rasmussen E (1977) The wasting disease of eelgrass (Zostera marina) and its effects on environmental factors and fauna.

Editorial responsibility: Managing Editors
In: McRoy CP, Hellferish C (eds) Seagrass ecosystems, a scientific perspective. Marcel Dekker, New York, p 1-51

Reigersman CJA, Houben GFH, Havinga B (1939) Rapport omtrent den invloed van de wierziekte op den achteruitgang van de wierbedrijven, met Bijlagen. Provinciale Waterstaat in Noord-Holland, Haarlem

Reise K, Herre E, Sturm M (1989) Historical changes in the benthos of the Wadden Sea around the island of Sylt in the North Sea. Helgol Wiss Meeresunters 43:417-433

Reise K, Jager Z, de Jong D, van Katwijk M, Schanz A (2005) Seagrass. In: Essink K, Dettmann C, Farke H, Laursen K, Lüerßen G, Marencic H, Wiersinga W (eds) Wadden Sea quality status report 2004. Wadden Sea Ecosystems No. 19, Common Wadden Sea Secretariat, Wilhelmshaven, p 201-207

Short FT, Wyllie-Echeverria S (1996) Natural and humaninduced disturbance of seagrass. Environ Conserv 23:17-27

> Short FT, Mathieson AC, Nelson JI (1986) Recurrence of the eelgrass wasting disease at the border of New Hampshire and Maine, USA. Mar Ecol Prog Ser 29:89-92

Short FT, Ibelings BW, den Hartog C (1988) Comparison of a current eelgrass disease to the wasting disease of the 1930s. Aquat Bot 30:295-304

Short FT, Burdick DM, Wolf J, Jones GE (1993) Eelgrass in estuarine research reserves along the east coast, USA, Part I: declines from pollution and disease and Part II: management of eelgrass meadows. NOAA Coastal Ocean Program Publ

Tocquet MA, Clément J, Tocquet A (1957) Carte bathymétrique des Iles Chausey réalisée d'après un levé exécuté d'après des sondages hydrographiques effectués en 1954 et 1955, carte au 1:10000ème. Electricité de France, Saint-Malo

van der Heide T, van Nes EH, Geerling GW, Smolders AJP, Bouma TJ, van Katwijk MM (2007) Positive feedbacks in seagrass ecosystems: implications for success in conservation and restoration. Ecosystems 10(8):1312-1322

van Katwijk MM, Hermus DCR, de Jong DJ, Asmus RM, de Jonge VN (2000) Habitat suitability of the Wadden Sea for restoration of Zostera marina beds. Helgol Mar Res 54: 117-128

Wilson DP (1949) The decline of Zostera marina L. at Salcombe and its effects on the shore. J Mar Biol Assoc UK 28:395-412

Submitted: October 24, 2007; Accepted: December 20, 2007 Proofs received from author(s): March 28, 2008 